\title{
Ocean modelling for aquaculture and fisheries in Irish waters
}

\author{
T. Dabrowski, K. Lyons, C. Cusack, G. Casal, A. Berry, and G. D. Nolan \\ Marine Institute, Rinville, Oranmore, Co. Galway, Ireland \\ Correspondence to: T. Dabrowski (tomasz.dabrowski@marine.ie)
}

Received: 21 May 2015 - Published in Ocean Sci. Discuss.: 25 June 2015

Revised: 16 November 2015 - Accepted: 30 November 2015 - Published: 15 January 2016

\begin{abstract}
The Marine Institute, Ireland, runs a suite of operational regional and coastal ocean models. Recent developments include several tailored products that focus on the key needs of the Irish aquaculture sector. In this article, an overview of the products and services derived from the models are presented. The authors give an overview of a shellfish model developed in-house and that was designed to predict the growth, the physiological interactions with the ecosystem, and the level of coliform contamination of the blue mussel. As such, this model is applicable in studies on the carrying capacity of embayments, assessment of the impacts of pollution on aquaculture grounds, and the determination of shellfish water classes. Further services include the assimilation of the model-predicted shelf water movement into a new harmful algal bloom alert system used to inform end users of potential toxic shellfish events and high biomass blooms that include fish-killing species. Models are also used to identify potential sites for offshore aquaculture, to inform studies of potential cross-contamination in farms from the dispersal of planktonic sea lice larvae and other pathogens that can infect finfish, and to provide modelled products that underpin the assessment and advisory services on the sustainable exploitation of the resources of marine fisheries. This paper demonstrates that ocean models can provide an invaluable contribution to the sustainable blue growth of aquaculture and fisheries.
\end{abstract}

\section{Introduction}

According to the Food and Agriculture Organisation of the United Nations, aquaculture is the fastest-growing foodproducing sector in the world (FAO, 2014). World capture fisheries production in marine waters has remained at stable levels over the last c. 30 years following steady growth in the preceding decades. The same report stresses the importance of implementing an ecosystem approach to fisheries. The most recent report published in Ireland shows that the total shellfish production doubled in the years 1990-2007 (Browne et al., 2008). Aquaculture is one of the five sectors targeted for further development under the European Union (EU) Blue Growth Initiative (European Commission, 2012); the fisheries sector has also been identified as crucial for jobs and value under this agenda.

In this context, one of the key needs of the aquaculture and fisheries sectors is the implementation of effective analyses and management methods to ensure the sustainability, economic viability, minimization of negative impacts on the environment, and risks to human health. Today, the above measures can be effectively supported by mathematical models, which can vary in complexity The examples include highly aggregated tools with low data requirements (e.g. ASSETS, Bricker et al., 2003), tools addressing the production and ecological sustainability at a finer spatial scale (e.g. Ferreira et al., 2007), and more detailed and complex research models. The latter comprise box models for the analysis of musselcarrying capacity (Filgueira and Grant, 2009), ecosystem models to determine food depletion (Grant et al., 2008), and 2-D or 3-D biogeochemical models coupled with shellfish models (e.g. Brigolin et al., 2009; Cugier et al., 2010; Dabrowski et al., 2013 and the references therein; Grangeré et al., 2009, 2010; Guyondet et al., 2010; Maar et al., 2009; Nunes et al., 2011; Ren et al., 2010). Numerical models used in studies on aquaculture and fisheries can themselves vary in complexity, from general ocean circulation models to sophisticated coupled physical-biogeochemical-shellfish ecophysiological models, such as that presented in Dabrowski et al. (2013).

The authors developed and maintain a suite of operational forecasting regional and coastal ocean models of Irish wa- 
ters. Several downstream services, driven by end-user requirements, have been developed in recent years to address some key needs of the aquaculture and fisheries industries in the region. This paper presents an overview of these modelbased products and services. In particular, those that relate to shellfish growth and carrying capacity, shellfish microbial contamination, harmful algae bloom warnings, offshore aquaculture site selection, cross-contamination of farms, and, fisheries assessments. The overview is preceded by a brief description of the operational models' set-up.

It should be noted that this paper is part of the Special Issue on operational oceanography in support of blue and green growth. Since sustainable growth across various marine sectors requires timely delivery of high-quality oceanographic products and services, the aim of this Special Issue is to inform the reader about the existing and ongoing developments in this regard. Within this context, the authors present the research results and the products and services that are at the different stages of advancements; some have already been published or are being published, as indicated throughout the paper, whereas others are still preliminary.

\section{Description of the models}

The 3-D operational models implemented by the Marine Institute are based on the Regional Ocean Modelling System (ROMS) which is a free-surface, hydrostatic, primitive equation ocean model described in Shchepetkin and McWilliams (2005). It uses orthogonal curvilinear coordinates on an Arakawa-C grid in the horizontal while utilizing a terrain-following (sigma) coordinate in the vertical. The prognostic variables of the hydrodynamic model are surface elevation, potential temperature, salinity, and horizontal velocities.

The local model of southwest Ireland, hereafter called the Bantry Bay model, consists of $557 \times 419$ grid cells relating to a horizontal spacing of $200-250 \mathrm{~m}$ and 20 vertical levels. The model is nested offline in a regional northeast Atlantic (NE_Atlantic) model run operationally at the Marine Institute and is a refinement of the latter by a factor of 5 . Time series of water levels, 2-D and 3-D momentum, temperature, and salinity are provided every $10 \mathrm{~min}$. The Bantry Bay model was initialized in February 2010 from the parent model output interpolated onto a child grid. Surface forcing is taken from the half-degree Global Forecasting System (GFS) that is available at 3-hourly intervals and the model interpolates data onto its current time step. Heat fluxes are calculated from the bulk formulae and surface freshwater fluxes are obtained from the prescribed rainfall rates and the evaporation rates calculated by the model. Freshwater discharges from five rivers are included in the model.

Some of the products and services presented in this paper concern another Irish coastal model that runs operationally and covers the midwest coast of Ireland, called the Connemara model. The set-up is analogous to that of the Bantry
Bay model. As regards to the works presented herein, this model has been used in the studies related with the offshore aquaculture planning (Sect. 3.4) and in the modelling of cross-contamination modelling between the aquaculture sites (Sect. 3.5). Model outputs utilized in the above studies consist of predicted currents. Hence, Fig. 2 presents relevant validation results. An acoustic Doppler current profiler (ADCP) was deployed in October 2011 at the location shown in Fig. 2a. Figure 2b presents a comparison of the depth integrated currents components in west-east ( $U$ velocity) and south-north ( $V$ velocity) directions between the model and ADCP.

The parent model domain (NE_Atlantic) covers a significant portion of the northwest European continental shelf and has a variable horizontal resolution, ranging from a value of $1.1-1.6 \mathrm{~km}$ in Irish coastal waters to $3.5 \mathrm{~km}$ in the south of the domain. There are 40 sigma levels in the vertical with a concentration of levels at the surface and the bottom. It is nested within the high-resolution $\left(1 / 12^{\circ}\right)$ Mercator Ocean PSY2V4R2 operational model of the North Atlantic, whereby daily values for potential, temperature, sea surface height, and velocity are linearly interpolated from the parent model onto the NE_Atlantic model grid at the boundaries. Tide forcing is prescribed at the model boundaries by applying elevations and barotropic velocities for 10 major tide constituents, which are taken from the TPXO7.2 global inverse barotropic tide model (Egbert and Erofeeva, 2002). The GFS atmospheric forcing is applied at the surface. The above model domains are presented in Fig. 1.

The Bantry Bay and northeast Atlantic models contain the biogeochemical module, which is based on the nutrient-phytoplankton-zooplankton-detritus model developed by Fennel et al. (2006). The model-governing equations remain the same as in Fennel et al. (2006); however, the rates of the following processes have been altered by the authors to achieve better model skill for Irish waters (see Dabrowski et al., 2014b): zooplankton grazing, nitrification rate, coagulation rate of small detritus and phytoplankton, small detritus remineralization rate and vertical sinking velocities of small detritus, large detritus, and phytoplankton. At the open boundaries of the Bantry Bay model, all biogeochemical model state variables are provided every $3 \mathrm{~h}$ and are interpolated from the "parent" northeast Atlantic biogeochemical model. The "parent" biogeochemical model is analogously set-up to the NE_Atlantic model described above, but is of coarser resolution $(\sim 5 \mathrm{~km})$ for computational efficiency reasons. The physical-biogeochemical coupling is "online", meaning it is a self-contained physicalbiogeochemical model.

The authors also developed a wave model based on SWAN (Simulating Waves Nearshore) (Booij et al., 1999) to estimate wave climate on the west coast of Ireland for offshore aquaculture sites. The model domain encompasses Irish coastal waters from 12.000 to $7.500^{\circ} \mathrm{W}$ and 50.000 to $56.500^{\circ} \mathrm{N}$ at a horizontal resolution of $0.004^{\circ}$. The model 


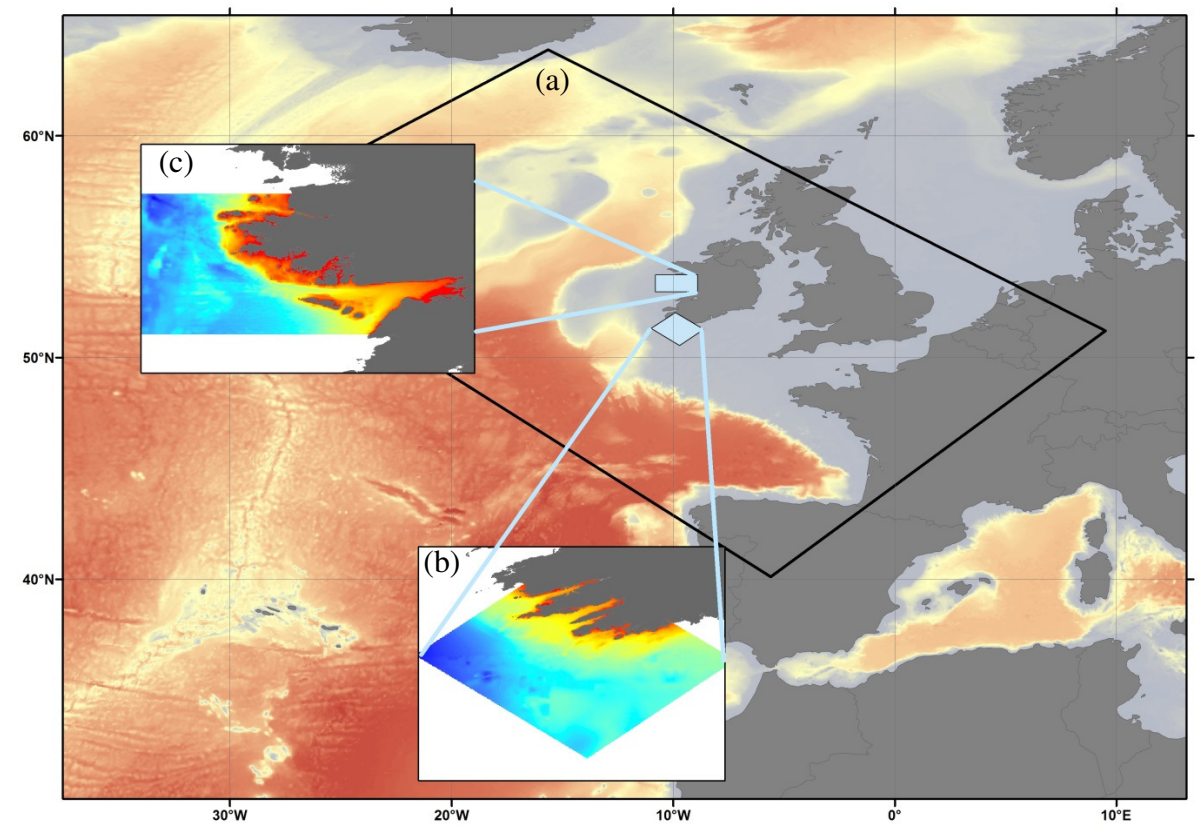

Figure 1. The Marine Institute operational general ocean circulation models domains: (a) NE_Atlantic, (b) Bantry Bay, and (c) Connemara.

is forced with winds from the GFS model and wave data at the boundaries from the Wave Watch 3 model developed by the U.S. Navy Fleet Numerical Meteorology and Oceanography Center (Tolman, 2009). Figure 3 presents scatter plots of modelled and observed significant wave height $(\mathrm{Hs})$ and wave period $(T z)$ from the south of the domain (M3) and towards the north of the domain (Inner Belmullet). The presented validation covers the time period January 2012February 2013 at a 1-hourly frequency. The observational data are available from the Marine Institute's ongoing operational observational programmes and can be accessed online (http://data.marine.ie/).

\section{Products and services}

\subsection{Shellfish ecophysiological model}

This biogeochemical module is further coupled to the shellfish ecophysiological model developed and implemented by Dabrowski et al. (2013). This shellfish model has been written for the species of Mytilus edulis (blue mussel) and Crassostrea gigas (Pacific oyster) and comprises two modules, namely the shellfish growth and the shellfish-ecosystem interactions. In Bantry Bay it has been implemented for the rope cultures of M. edulis. The growth model is a Fortran 90 implementation of the Dynamic Energy Budget (DEB) algorithm (Kooijman, 2010) and the shellfish-ecosystem coupler is a new model developed by the authors and presented in detail in Dabrowski et al. (2013). The following processes are included: food uptake and assimilation of nitrogen and carbon in bivalve, egestion of faeces, $\mathrm{NH}_{4}$ excretion, oxygen utilization, and $\mathrm{CO}_{2}$ production. The food comprises phyto- plankton and small detritus and the model dynamically adjusts food preferences through the inclusion of the food selection factor, and the egestion of faeces adds to the large detritus pool in the model.

The shell length, $L$, and dry weight, DW, are derived from the model, as these are important parameters from the farm operations and management perspectives and they have an impact on the price. Dabrowski et al. (2013) present the distribution of predicted $L$ after c. 1-year simulation carried out for the period 2010-2011 (Fig. 7 therein). Results were validated and compare well with data collected in the bay over the same time period. The areas offering good growth potential (i.e. greater $L$ ) can be distinguished from poorer growth areas (i.e. lower $L$ ) using this model.

The presented model can thus answer two overarching questions: what is the spatial distribution of growth potential in the bay? Secondly, what impacts on the ecosystem are exerted by the farms (e.g. depletion of phytoplankton, dissolved inorganic nitrogen enrichment)? The above studies are therefore useful for the estimation of production and ecologicalcarrying capacities enabling informed management decisions to be made by the authorities responsible for the aquaculture sector. The production and ecological-carrying capacities are interlinked and concern the studies on maximum production that the environment can sustain. Since the presented model is implemented in 3-D and includes ecological interactions, the carrying capacity issues can be addressed, for example, by running the experiments with alterations to standing stocks, relocation or removal of the existing farms, addition of new farms or change to farming practices (e.g. time of harvesting, rope vs. bottom cultures) 
(a)

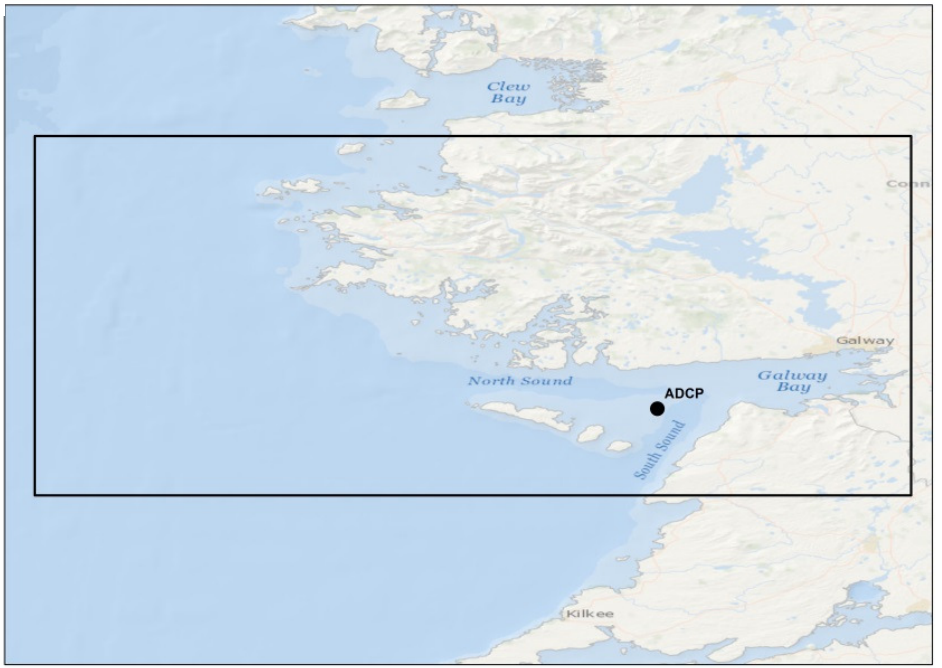

(b)
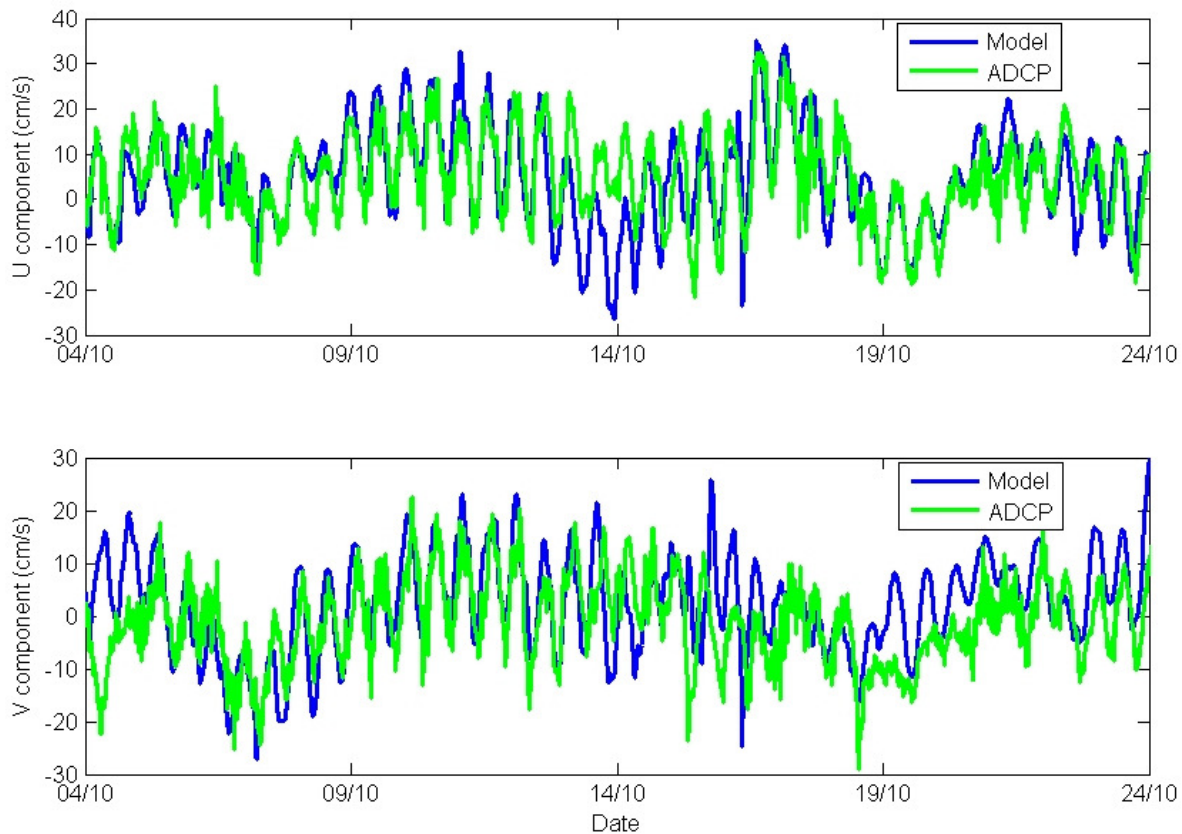

Figure 2. Results from the validation of the Connemara model: (a) location of ADCP, (b) comparison of modelled and observed depth integrated $U$ and $V$ velocity components.

\subsection{Shellfish microbial contamination}

The model described in Sect. 3.1 has been further extended to include a microbial module developed by and presented in Dabrowski et al. (2014a). In the above paper the authors present a new method to simulate an uptake of $E$. coli from seawater and subsequent depuration by $M$. edulis that dynamically predicts $E$. coli concentration in the mussel tissue. Concentration of $E$. coli in water is determined by its die-off rate (dependent on light, temperature, and salinity following Canteras et al. (1995) and recently successfully used by Mateus et al. (2013)), the rate of uptake by mussels, and the rate of input from the point sources in Bantry Bay. Depuration in the mussel tissue follows a first-order decay and assumes a constant $T_{90}$ of $3 \mathrm{~h}$, which yields a decay rate of 18.4 day $^{-1}$. Dabrowski et al. (2014a) derived an equation for the filtration rate using the energy ingestion rate predicted by the DEB model for M. edulis. This energy ingestion rate is converted 
(a)

(b)
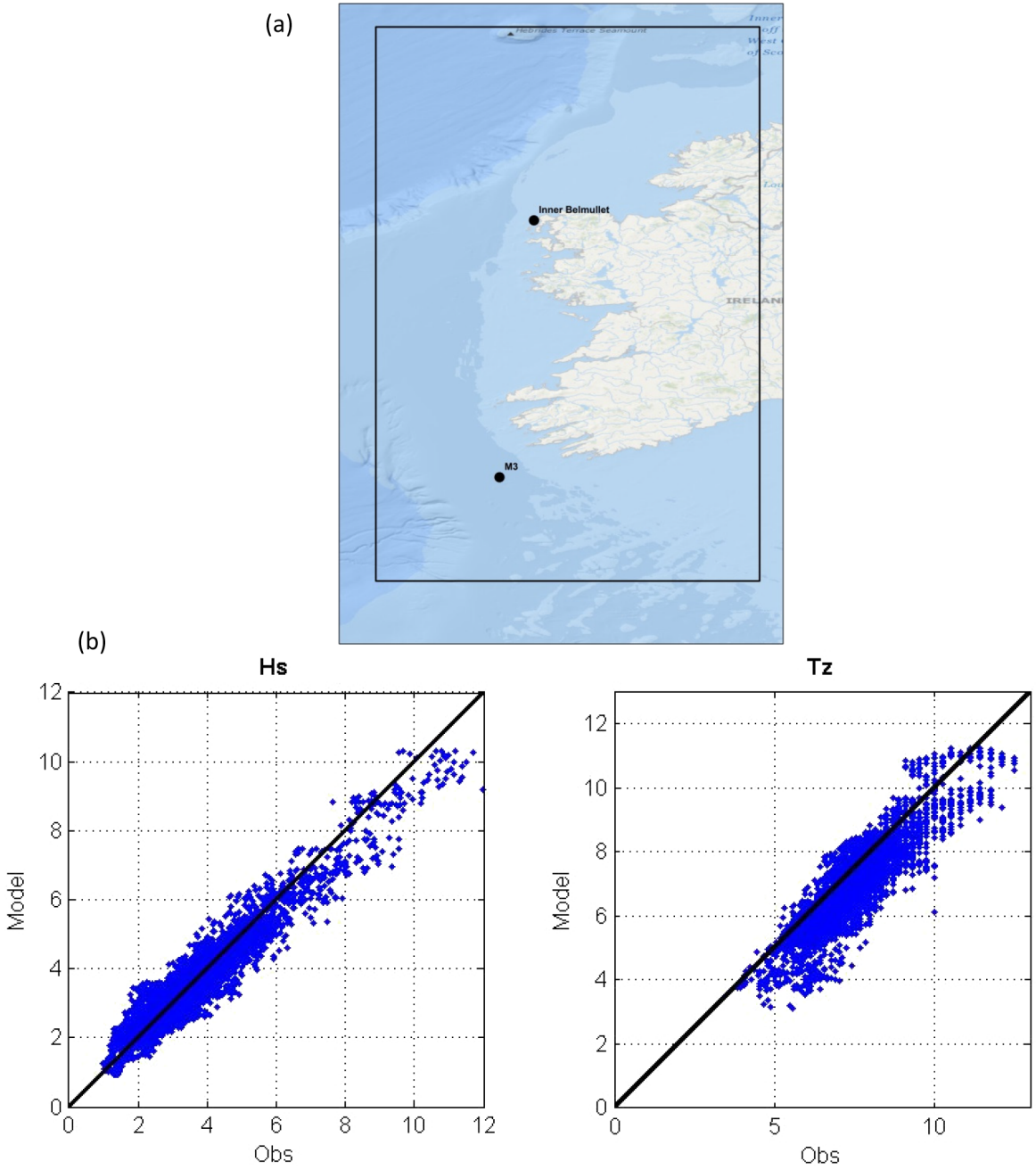

(c)
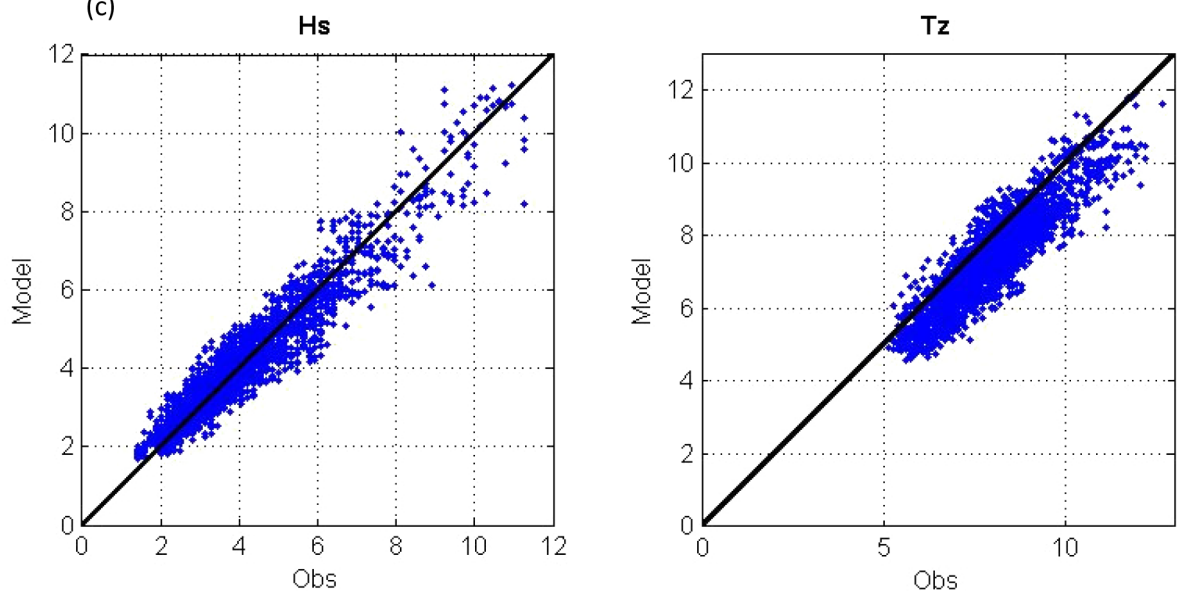

Figure 3. Results from the validation of the wave model: (a) model domain and locations of buoys, (b) and (c) scatter plots of modelled vs. observed significant wave height and wave period at Inner Belmullet site and M3 sites, respectively.

to carbon ingestion rate and its uptake in food is subsequently calculated. Phytoplankton is one of the food sources in the model; therefore the filtration rate can be expressed in terms of the ratio of phytoplankton carbon ingestion rate to phytoplankton carbon concentration. 
The above approach proved to be successful in the modelling study of the rope mussel coliform contamination in Bantry Bay as presented in Dabrowski et al. (2014a). Shellfish water classes defined in the EC directive (European Commission, 2006) and based on coliform concentration in shellfish flesh were derived from the model. In the above paper, the authors present the distribution of these water classes in Bantry Bay (Fig. 6 therein); these compare well with the classes established based on the national monitoring programme.

Some overarching questions that can be addressed by the presented model include the following.

- How does new/existing outfall have an impact on shellfish waters?

- Is it a safe location for a new farm?

- What is the best time for harvesting (based on shortterm forecasts if implemented operationally)?

\subsection{HAB warning}

A number of customized products are generated from the Bantry Bay model and are intended to improve the knowledge on driving forces behind harmful algae bloom (HAB) events off southwest Ireland. Dabrowski et al. (2016) provides in-depth details on the validation of the Bantry Bay model that is deemed suitable for operational use in a HAB nowcast/forecast system. The products include Bantry Bay cross sections at the mouth of the bay and midway between the mouth and the head, showing 3-day averaged volumetric flows and their vertical structures as well as the temperature, salinity, and density profiles. The magnitudes of the current inflows are also compared to their long-term means in order to identify pronounced events. These products along with other (e.g. satellite data: sea surface temperature and chlorophyll, data from the national harmful algal bloom and shellfish biotoxin monitoring programme) constitute part of a weekly HAB bulletin published online. Cusack et al. (2016) show how this model is used in the HAB forecast and how all of the above products provide information on the likelihood of HAB outbreaks in the bay. Table 1 summarizes the products that are currently used by local expert to generate the bulletin.

Another operational product is based on the predicted tracks of the particles released at the surface layer, at $20 \mathrm{~m}$ depth and at the bottom layer across the mouth of Bantry Bay and a transect perpendicular to the coast, through offshore waters, southeast of Bantry Bay at Mizen Head. The passive particles are released at the above transects over the first $12 \mathrm{~h}$ and at $30 \mathrm{~min}$ intervals upon the execution of each simulated 3-day forecast. The end products are maps (one per transect and release depth) presenting the total time spent by all particles at each model computational cell over the duration of the forecast, the so-called particle-hours, and the maps are available online (http://vis.marine.ie/particles). An example map is presented in Fig. 4. The maps aim to quantify the strength of shelf water inflow into Bantry Bay, highlight upwelling/downwelling events, and depict the strength of the Irish coastal current. Furthermore, a set of Matlab scripts has been developed allowing the execution of the particle transport model upon notification of suspected toxic bloom locations from the observational platforms and from institutions in other countries that provide forecasts of harmful algae trajectories based on particle tracking, which allows for interregional forecasts. The data exchange is facilitated by KML format and e-mail alerts are issued when particles cross the respective model boundaries.

Ireland's southwest coast frequently experiences shellfish farm closures due to HABs. Contaminated shellfish can take many months, especially in winter, to depurate the HAB biotoxins. Depuration times can be highly variable and are likely related to food availability among other things, such as the metabolic rate of the bivalves (Marcaillou et al., 2010; Jauffrais et al., 2012). A HAB warning system will give farmers the opportunity to extract product before long closures occur. In 2013, one or more farms were closed when biotoxins in shellfish were above the EU regulatory limit for a period of 35 weeks (Cusack et al., 2016). A diarrhoeic shellfish poisoning (DSP) event occurred in July and lasted $\sim 9$ weeks, while an azaspiracid shellfish poisoning (AZP) event in October lasted $\sim 11$ weeks. Biotoxin levels in the bay's blue mussels increased quickly when the causative organisms, Dinophysis (DSP biotoxins) and Azadinium-like species (AZP biotoxins), increased in the bay. Figure 5 shows that both events were linked to downwelling when offshore surface water masses entered the bay.

Another economic threat to the Irish shellfish industry is a biotoxin called domoic acid (DA). It can cause a serious human illness called amnesic shellfish poisoning that can induce, in extreme cases, symptoms of memory loss and even death. The rate that DA is excreted from shellfish is species-specific. For example, the blue mussel (Mytilus edulis) quickly clears DA (Novaczek et al., 1991, 1992; Wohlgeschaffen et al., 1992). This is evident in the rapid increase and decline of a small Pseudo-nitzschia bloom and associated DA in long-line mussel cultures after an upwelling event occurred in Bantry Bay in April 2013 (Fig. 5). Overall, from April to October 2013, five downwelling events were evident in the volumetric flux simulations; three were linked to harmful algal blooms and diarrhoeic shellfish poisoning (DSP) and azaspiracid shellfish poisoning (AZP) threats (Fig. 5b-c). Modelling results showed 11 upwelling events; two were associated with potentially toxic diatom blooms, Pseudo-nitzschia and ASP threats, and one was linked to the appearance in Bantry Bay of a fish-killing dinoflagellate called Karenia mikimotoi (Fig. 5a). As can be seen in Fig. 5d-e, increased inflows into the bay relate well with identified strong upwelling and downwelling events. Cusack 
Table 1. List of products used to generate weekly HAB bulletin.

Product
$\begin{aligned} & \text { Current conditions and } \\ & \text { predictions }\end{aligned}$
$\begin{aligned} & \text { Harmful and/or toxic algal bloom and biotoxins national monitoring programme data } \\ & \text { are presented. } \\ & \text { The products include the following: }\end{aligned}$
$\begin{aligned} & \text { a. biotoxin report for the last week (whole tissue long-line mussels and oysters); } \\ & \text { b. HAB report for the last week; } \\ & \text { c. Ireland historic trends (What happened this week over the past } 10 \text { years?); 2003- } \\ & 2012 \text { harvesting closures (biotoxins above regulatory levels); } \\ & \text { d. biotoxin prediction for the current week; includes a rationale. } \\ & \text { e. biotoxin and HAB distribution maps of importance for the last } 3 \text { weeks; } \\ & \text { f. data plotted on a weekly basis from week 1 to the current week to allow the user } \\ & \text { to view upward and downward trends in the national data set. }\end{aligned}$

Satellite observations The most up-to-date daily satellite map is presented to provide large-spatial-scale information on surface phytoplankton blooms (chl $a$ measurements) and sea surface temperature (SST). Karenia mikimotoi cell densities from the national data set are overlayed on a weekly chl $a$ anomaly map. The composition of near-shore phytoplankton communities are described in detail with some highlights for the most recent week. In situ national weather buoy network SST data for the week in question (includes the weekly anomaly from a 10-year mean) are presented alongside the satellite SST maps.

Bantry Bay model Bantry Bay model is a hydrodynamic model of the shelf sea off southwest Ireland with horizontal resolution of $200-250 \mathrm{~m}$ and 20 vertical levels. It is an application of a widely used primitive-equation, free-surface, hydrostatic ROMS model and its prognostic variables consist of surface elevation, potential temperature, salinity, and water velocities. A number of ASIMUTH-tailored products are derived from the model:

a. prediction of Lagrangian water transport from the Mizen Head (south of Bantry Bay) and the Bantry Bay mouth transects based on particles released at the surface, at $20 \mathrm{~m}$, and at the bottom

b. prediction of Eulerian water transport at the Bantry Bay mouth and inner Bantry Bay transects

c. cross section through water temperature, salinity, and density at Bantry Bay mouth

d. current total volumetric inflow of water into Bantry Bay through the cross section at the mouth and in inner Bantry Bay

Northeast Atlantic model
The northeast Atlantic model encompasses all of Ireland's territorial waters and beyond. It became operational in 2008, and, similarly to the Bantry Bay model is an implementation of ROMS. The model domain covers a significant portion of the northwest European continental shelf and also the Porcupine and Rockall banks and the Rockall Trough at a variable horizontal resolution, ranging from $1.1-1.6 \mathrm{~km}$ in Irish coastal waters to $3.5 \mathrm{~km}$ in the south of the domain. There are 40 sigma-coordinate vertical levels with a concentration of levels at the surface and the bottom.

Within ASIMUTH, the model is primarily used as the boundary conditions provider for the Bantry Bay model and for predicting the transport of Dinophysis spp. blooms by water currents across the region based on particle tracking (including the interregional transport). et al. (2016) showed that the model provides reliable estimates of water exchange events in Bantry Bay.

The model-derived products are integrated and used as part of a "toolkit" to estimate the risk to inshore shellfish farms. The current HAB warning system for Ireland includes historical data (time of past toxic events) used to determine the seasonal temporal window for HABs; HAB and shellfish biotoxin maps for the most recent 3 weeks, used to show temporal and spatial changes at more than 100 stations around the Irish coast; and daily spatial remotely sensed sea surface 


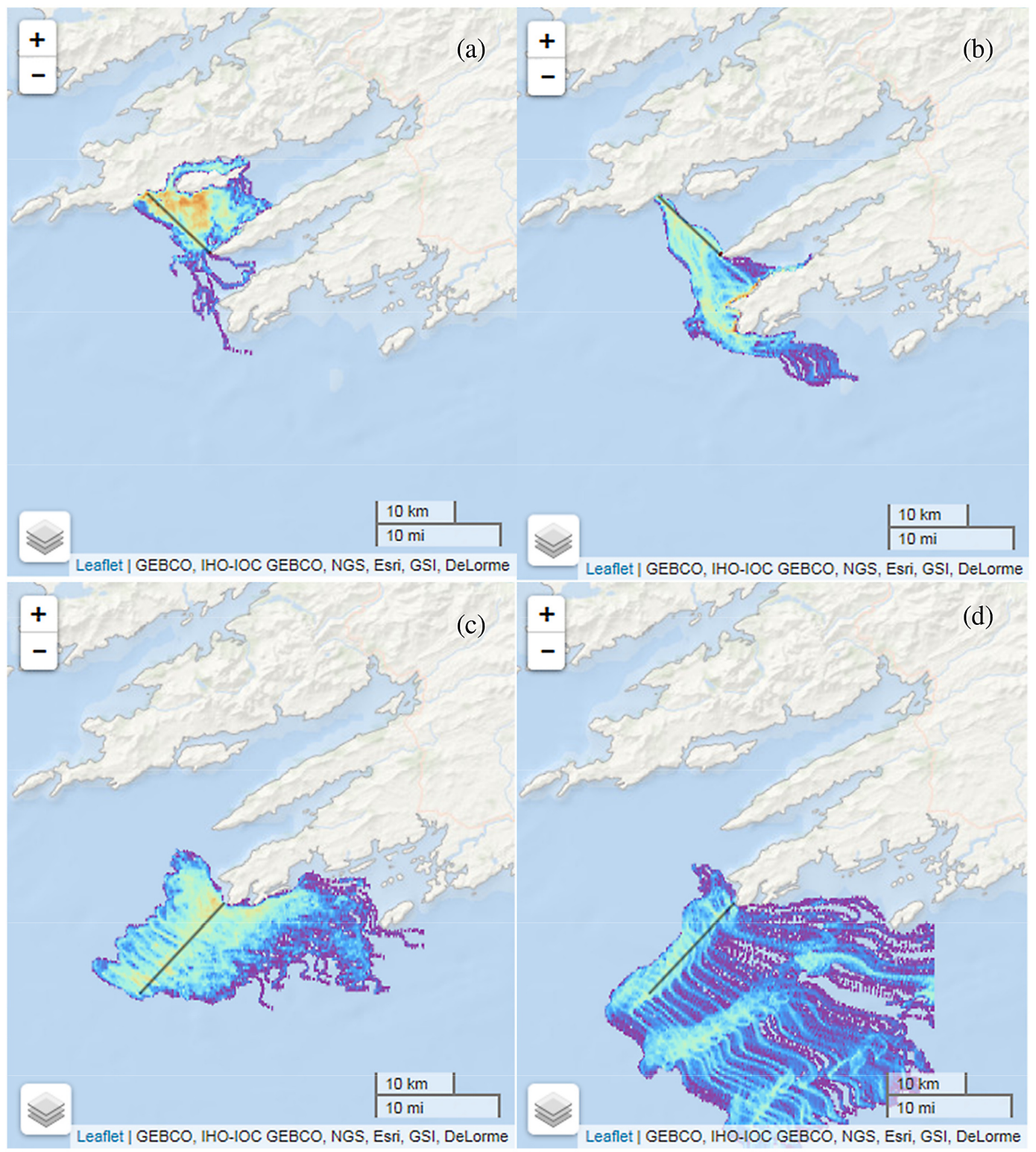

Figure 4. The particle-hours map from the 3-day forecast starting on 27 April 2015: (a) and (c) particles released at the bottom layer, (b) and (d) particles released at the surface layer along the presented transects. Colour scheme: purple - low values, orange - high values.

temperature (SST) and chlorophyll, used to detect and monitor the surface appearance of high biomass nuisance HABs. As can be seen in Fig. 5, false positive alerts can, however, occur for Bantry Bay when a water exchange event is predicted by the model, but HABs are not transported inshore. It is therefore evident that a shelf ocean observing system is needed to provide the offshore HAB abundance data. More detailed discussion can be found in Cusack et al. (2016).

\subsection{Offshore aquaculture}

Offshore aquaculture development requires accurate knowledge of environmental conditions (e.g. weather and wave climate; characteristics of water currents) at proposed sites. Knowing the environmental conditions over a large area facilitates intelligent, targeted site selection for offshore aquaculture development. Site classification can be achieved by considering a number of factors such as exposure (e.g. wave, wind, currents), accessibility (which is related to exposure), and distance to shore/infrastructure.

The literature has a number of examples of attempts to classify sites, usually based on a combination of exposure (e.g. wave, wind, currents), accessibility (which is related to exposure), and distance to shore/infrastructure (e.g. Ágústsson, 2004; Perez et al., 2003; Ryan, 2004). There does not seem to be a strong consensus on the number of classes and 

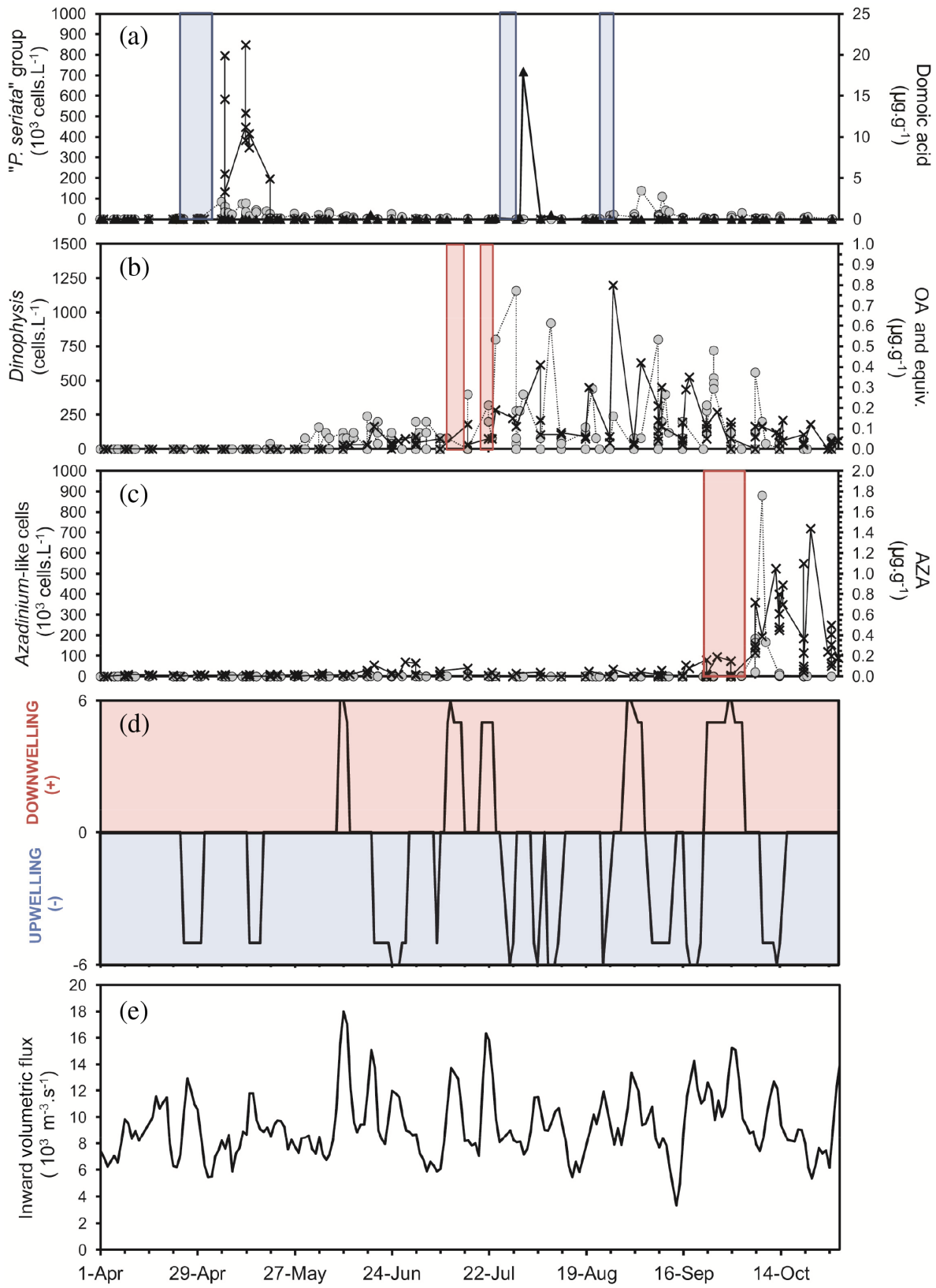

Figure 5. Harmful algal bloom events and model results, Bantry Bay, April to October 2013; concentrations of (a) Pseudo-nitzschia ("o"), Karenia mikimotoi ("凶") and DA ("x"), (b) Dinophysis ("o") and OA and equivalents ("x") and (c) Azadinium-like dinoflagellates ("o") and AZAs ("x"); (d) upwelling and downwelling events in the bay, (e) volumetric inflow to the bay; blue and red boxes overlaid on panels (a-c) relate to upwelling and downwelling, respectively.

the exact criteria to use, but Holmer (2010) describes three classes of sites and these are presented in Table 2.

A geographical information system (GIS) is the ideal platform for this type of decision support tool. A GIS-based model can incorporate and analyse large amounts of spatial data and produce simple visual displays of the results. The authors created a number of GIS raster layers for northwest coast of Ireland. The layers were (i) water depth; (ii) maximum tidal velocity (based on harmonics derived from a 1-year run of the NE_Atlantic model); (iii) $90 \%$ percentile value of a significant wave height (Hs), Hs_P90, and (iv) maximum max_Hs. The wave parameters (Hs_P90 and max_Hs) were derived from a 13-month simulation of the wave model (January 2012-February 2013) described in Sect. 2. The layers were imported into ESRI's ArcGIS to facilitate spatial analysis.

Simple raster analysis was used to apply rules to the individual layers to isolate areas where certain exposure cri- 
Table 2. Classification of aquaculture sites (after Holmer, 2010).

\begin{tabular}{llll}
\hline & Coastal farming & Off-coast farming & Offshore farming \\
\hline Physical setting & $<500 \mathrm{~m}$ from shore & $500 \mathrm{~m}$ to $3 \mathrm{~km}$ from shore & $>3 \mathrm{~km}$ from shore \\
& $<10 \mathrm{~m}$ water depth & 10 to $50 \mathrm{~m}$ water depth & $>50 \mathrm{~m}$ water depth \\
& Within sight of shore users & Usually within sight & Not visible from shore \\
& & & Waves up to $5 \mathrm{~m}$ \\
Exposure & Waves $<1 \mathrm{~m}$ & Waves $<3$ to $4 \mathrm{~m}$ & Ocean winds \\
& Local winds & Localized winds & Ocean swell \\
& Local currents & Localized currents & No tidal currents \\
& Strong tidal currents & Weak tidal currents & Exposed \\
& Sheltered & Somewhat sheltered & $>80 \%$ accessibility \\
& $100 \%$ accessibility & $>90 \%$ accessibility & Outside coastal baseline \\
& Within coastal baseline & Within coastal baseline & National/international waters \\
\hline Legal definitions & National waters & National waters & USA (Hawaii) \\
& China & Chile & Spain (Canaries) \\
\hline Examples of major producers & Chile & Norway & Mediterranean \\
& Norway & &
\end{tabular}

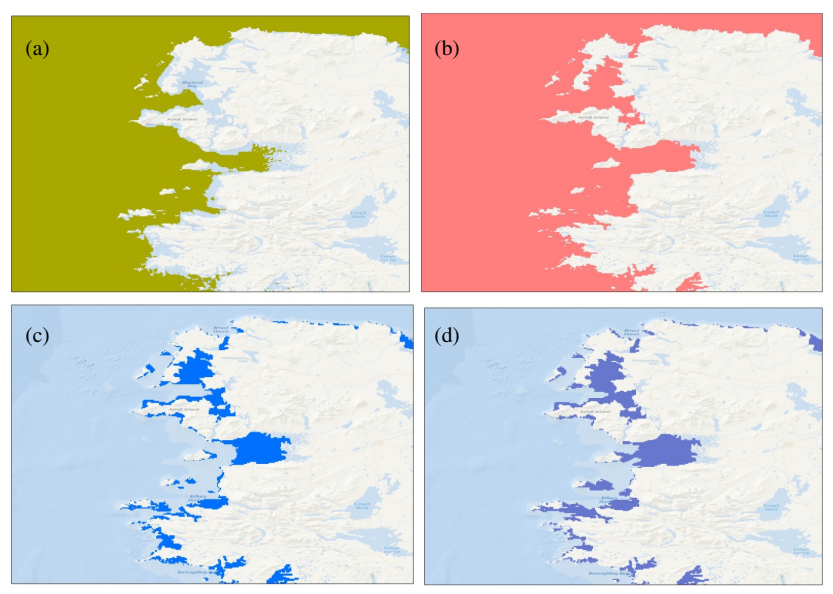

Figure 6. Spatial extents of (a) depth $\geq 15 \mathrm{~m}$, (b) maximum tidal velocity $<1 \mathrm{~m} \mathrm{~s}^{-1}$, (c) max_Hs $<4 \mathrm{~m}$, and (d) Hs_P90 $<2 \mathrm{~m}$ for the west coast of Ireland.

teria were met. Using the "Off-coast farming" classification of Holmer (2010) as a rough guide, the following simple model to highlight potential sites was enforced: water depth $\geq 15 \mathrm{~m}$, maximum tidal velocity $<1 \mathrm{~m} \mathrm{~s}^{-1}$, max_Hs $<4 \mathrm{~m}$, and Hs_P90 $<2 \mathrm{~m}$. Figure 6 visually demonstrates the spatial extent resulting from the application of each rule separately for the northwest coast of Ireland. The superposition of the four layers shown in Fig. 6 was used to create a new raster. The resulting raster contains binary data: cell values of 1 where all the criteria are met and cell values of 0 where one or more of the criteria failed. Figure 7 shows the spatial extent of the cells with value of 1 . These equate to the location of potential offshore aquaculture sites for this simple model.
With the addition of more geographical information (e.g. location of infrastructure) this type of GIS model can become a powerful decision support tool to aid in the selection and development of offshore aquaculture sites. The GIS model can be improved by including more raster layers, for example 50/100 return periods for wave height and wind speed, and environmental impact data such as location of Special Areas of Conservation, in which case the environmental impact of potential sites can also be included in the site selection process.

\subsection{Cross-contamination of farms}

The risk of infection to salmon stock by sea lice is recognized as a serious issue for the salmon farming industry. Infection of salmon within and between farms occurs during the planktonic copepodid stage of the louse life cycle. Since the dispersal of planktonic larval salmon lice is largely controlled by surface currents, it is possible to simulate their dispersal using hydrodynamic modelling. The results can be used to indicate infection pressure risk in bays where salmon farms are situated or proposed.

For this study, the Connemara model was run with Lagrangian particle tracking activated. This allows the introduction of model particles into the domain at a location of the user's choosing (e.g. a salmon farm) and the particles are advected around the domain by the model currents. The model particles behave as passive drifters with neutral buoyancy. The particles were released near the surface at the locations of the aquaculture farms in the region every $3 \mathrm{~h}$ for 35 days and the location of each particle was recorded over the duration of 14 days (the particles were assumed to have a "lifespan" of 14 days, after which they were considered "dead", i.e. excluded from the analysis). The particle-hours, defined 


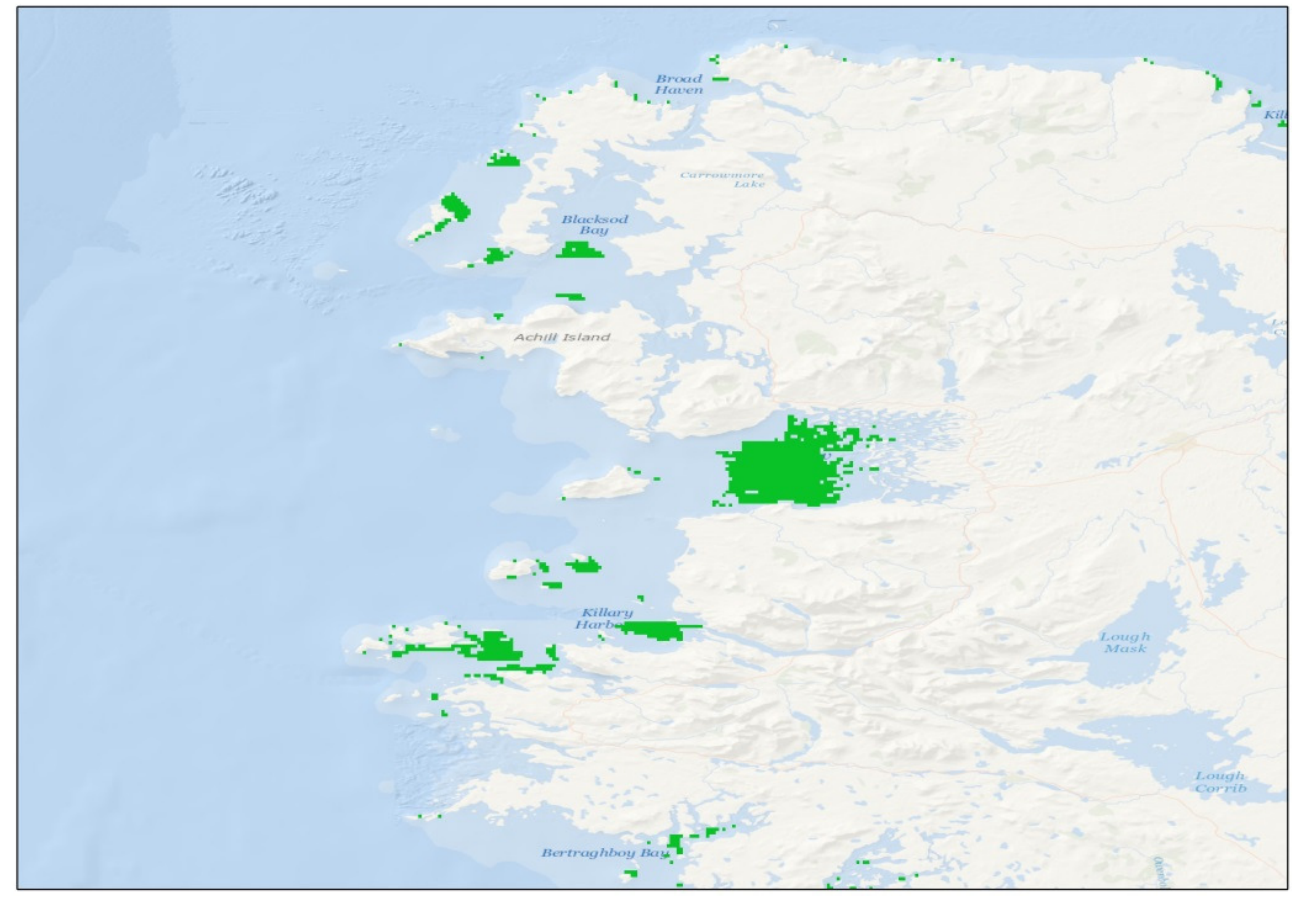

Figure 7. Potential offshore aquaculture sites (green) off the west coast of Ireland.

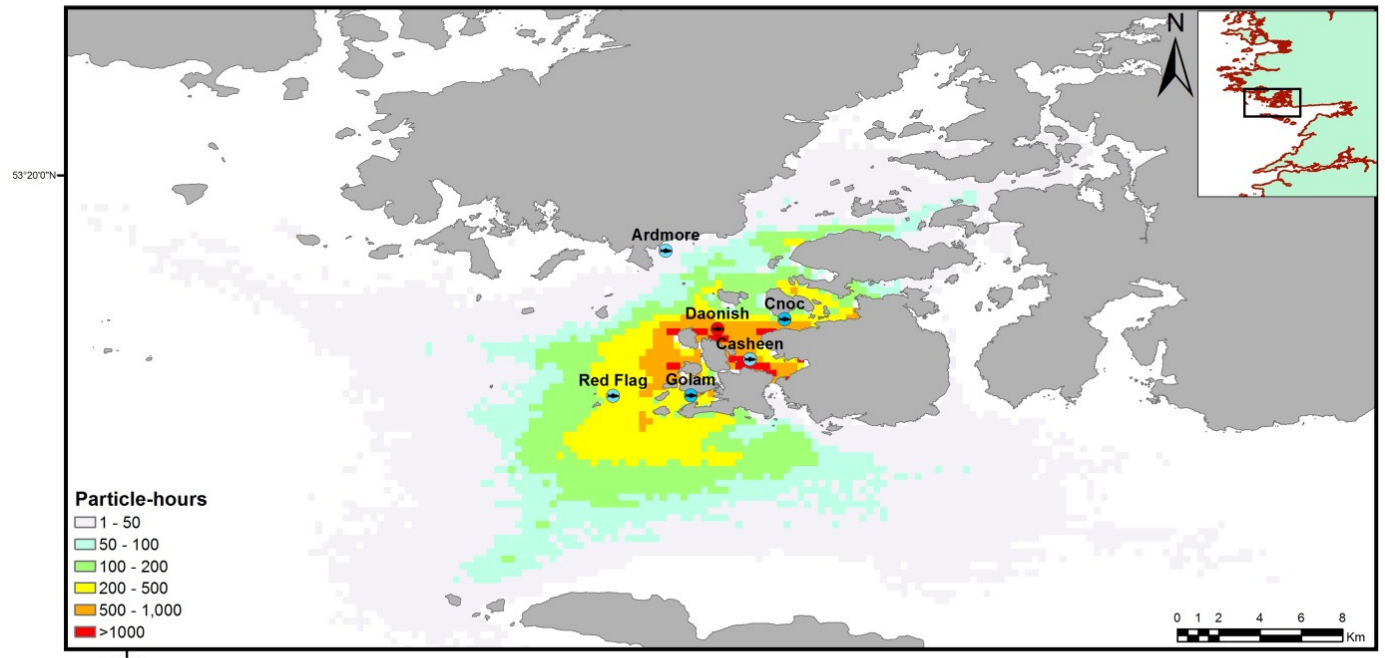

Figure 8. Sea lice infection risk map from Daonish farm located in the west of Ireland (after Jackson et al., 2012).

in Sect. 3.3, were then calculated for each model cell and from this the authors derived maps of relative infection risk for fish in each cell of the model domain. An example map for the infection risk from Daonish farm on the west coast of Ireland is presented in Fig. 8.

The results of the particle track analyses can also be used to create a cross-contamination matrix for a collection of salmon farms in a bay. In this study, each salmon farm was defined as a $500 \mathrm{~m}$ square centred on the particle release site used for the Lagrangian particle tracking. Then the cumula- tive particle-hour value for that salmon farm due to particles released from each of the other sites in the bay was calculated. The numbers derived from this analysis were placed in a matrix in order to quantify the relative risk of infection from one farm to another. Table 3 is an example of a matrix developed from three release sites (locations visible in Fig. 8). Referring to the Daonish release site in Table 3, the high value (1359) for Casheen indicates that this farm has an elevated risk of sea lice infection from Daonish compared to the other farms in the vicinity. The cross-contamination ma- 
Table 3. Cross-contamination matrix for salmon aquaculture farms in the west of Ireland.

\begin{tabular}{lrrrrr}
\hline \multirow{2}{*}{ Release sites } & \multicolumn{5}{c}{ Receiving sites } \\
\cline { 2 - 6 } & Casheen & Cnoc & Daonish & Golam & Red flag \\
\hline Cnoc & 129 & & 202 & 111 & 525 \\
Daonish & 1359 & 129 & & 73 & 439 \\
Golam & 155 & 37 & 206 & & 237 \\
\hline
\end{tabular}

trix along with the risk maps are potentially useful tools in sea lice management strategies and in the selection process for new farms. More results from the presented study can be found in Jackson et al. (2012).

A very similar approach has been used by the authors in a project, Aquaplan, that brought together key stakeholders from the aquaculture industry and state agencies in Ireland, and which aimed at providing the basis for the development and implementation of a Strategic Plan for Fish Health Management in Ireland. The authors conducted the disease connectivity modelling for a total of 23 sites in the west of Ireland and developed the cross-contamination matrix. The report from the project was published in 2015 (Ruane et al., 2015).

\subsection{Products for fisheries}

Output from the Marine Institute operational models also underpins the assessment and advisory services on the sustainable exploitation of the resources of marine fisheries in the waters around Ireland and on the impacts of fisheries on the ecosystem. Monthly and annual averages of selected modelled state variable from the ocean circulation and wave models are produced routinely. These include surface and bottom temperatures, surface and bottom salinities, surface velocity, bottom shear stress, mixed layer depth, significant wave height, mean wave direction, and mean wave period. Most of the above products are published on the centralized Marine Institute data portal at http://data.marine.ie/ and on the ERDDAP http://erddap.marine.ie/ and THREDDS servers, allowing a data download in variety of formats to suit the end users' individual requirements. ERDDAP (Simons, 2015) is a data server that gives a simple consistent way to download subsets of gridded and tabular scientific data sets in common file formats and make graphs and maps. The authors also maintain an archive of 3-hourly model prognostic variables from a hindcast run for 3-D currents and temperatures in Irish waters from the NE_Atlantic model, which is used to force an offline particle tracking model LTRANS (Schlag and North, 2012), used to investigate fish larvae transport. Readers are referred to O'Sullivan et al. (2015) for details on the study of the potential dispersal fields of Nephrops larvae from individual fishing grounds and the assessment of stock connectivity using the output from the models.
The above model-derived outputs are supplemented by further products from the observational platforms, namely the satellites and the Marine Institute marine observation network, that are tailored to the fisheries' research requirements. Daily optimum interpolation SST for the period 1982 to 2014 produced by the USA National Oceanic and Atmospheric Administration (Reynolds et al., 2007) were downloaded for processing. This data set also uses the in situ data from ships and buoys and includes a large-scale adjustment of satellite biases with respect to the in situ data. Validation of monthly SST data derived from the above product against monthly in situ temperatures from the buoy networks operated by the Marine Institute around Ireland is presented in Fig. 9. Annual SST averages were derived by the authors and exported in the GeoTIFF and NetCDF formats. The annual averages were then spatially averaged for the International Council for the Exploration of the Sea (ICES) subareas and divisions in Irish waters. ICES divisions considered in this study are presented in Fig. 10a. Figure 10b also shows a time series of annual SST in ICES subareas west of Scotland (divisions VIa-b) and the Celtic Sea (divisions VIIa-k). The analyses revealed that there is a clear increasing SST trend in both zones. If the most recent 10 years are taken into account, the SST in the Celtic Sea has undergone an annual increase of $0.33^{\circ} \mathrm{C}$ $( \pm 0.02)$, while in the west of Scotland the average annual increase is $0.54^{\circ} \mathrm{C}( \pm 0.04)$. These results are coincident with the global SST trend and with the general trend in other studies carried out in Irish waters (Cannaby and Hüsrevoglu, 2009; Nolan et al., 2010; Olbert et al., 2011, 2012). Annual anomalies referenced to the 1971-2000 climatologies along with the error standard deviations for every year were also produced. The authors also developed analogous data sets for chlorophyll $a$ separately for various ocean colour sensors i.e. CZSC (1982-1986), SeaWIFS (1997-2010), MERIS (20022012) and MODIS-Aqua (2002-2014). Since chlorophyll $a$ concentrations derived from the many sensors vary, work is ongoing to produce a consistent long-term data set for Irish waters, also taking different algorithms for Case 1 and Case 2 waters into account. Further details of this work can be found in Casal et al. (2015).

Monthly SST observations and anomalies at Marine Institute fixed ocean observation stations are also of interest to the fisheries. The authors produce graphs of current monthly mean SST along with the standard deviations and minimum and maximum temperatures recorded in a given month since records began at the individual stations that are part of the Irish National Weather Buoy Network. These graphs are included in the Monthly Oceanographic Bulletin, currently an internal Marine Institute publication, and Fig. 11 shows the example of the product for the $\mathrm{M} 3\left(51.216^{\circ} \mathrm{N}, 10.550^{\circ} \mathrm{W}\right)$ and M4 $\left(55.000^{\circ} \mathrm{N}, 10.000^{\circ} \mathrm{W}\right)$ buoys in 2014 . The M3 station data have been included in the ICES Report on Ocean Climate 2012 (Beszczynska-Möller and Dye, 2013). 


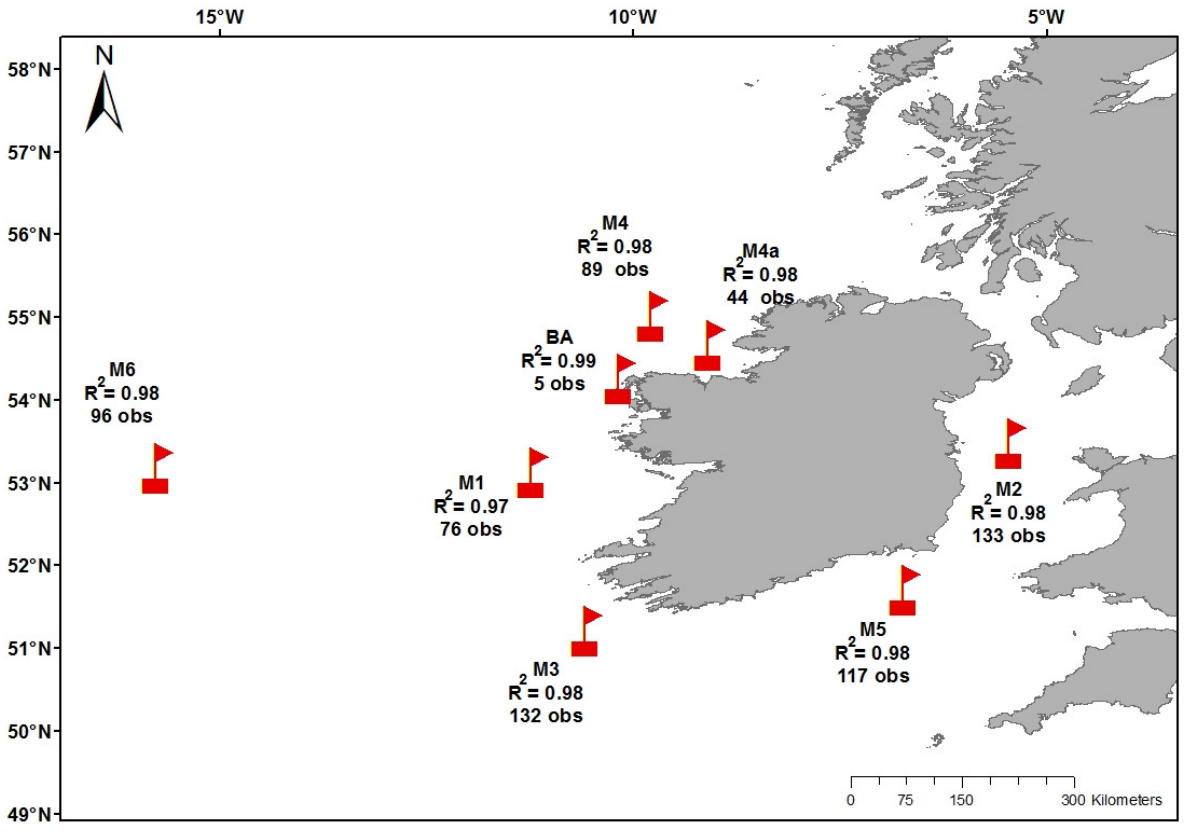

Figure 9. Coefficients of determination for monthly satellite SST against in situ SST at the locations of the buoys operated by the Marine Institute.

(a)

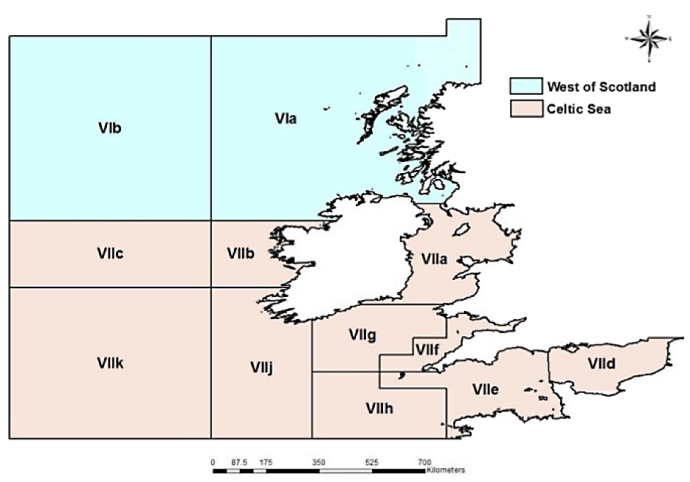

(b)

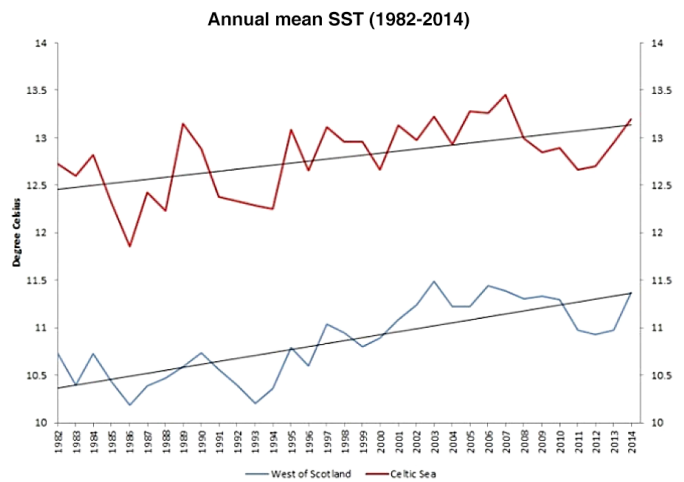

Figure 10. (a) ICES divisions around Ireland and (b) time series of annual SST for the west of Scotland (divisions VIa-b) and the Celtic Sea (divisions VIIa-k) subareas (after Casal et al., 2015).

\section{Summary and conclusions}

There is an increased interest in using computer models as tools for sustainable management of coastal ecosystems, accounting for multiple uses, including aquaculture and fisheries. The numerical models remain an appropriate vehicle to further our understanding of the complex interactions between ecological processes in marine ecosystems and thus enable end users to make more informed management decisions. The level of spatial and temporal detail offered by these models, their forecasting and hypothesis, and scenariotesting capabilities are virtually unachievable through the monitoring programmes alone. Cost-effective solutions in social and economic dimensions and measures aimed at protection of marine environments can be then implemented. Risks such as losses in ecosystem services, greater incidence of diseases, and increased occurrence of harmful algal blooms can be mitigated or reduced with the aid of modelling services. The contribution that ocean models can make to the sustainable blue growth of aquaculture and fisheries is thus invaluable.

The authors presented an overview of numerous products and services based on the operational ocean modelling system developed in recent years at the Marine Institute, Ireland, and which have been tailored to address several key needs of the aquaculture and fisheries sectors in Irish waters. 
(a)

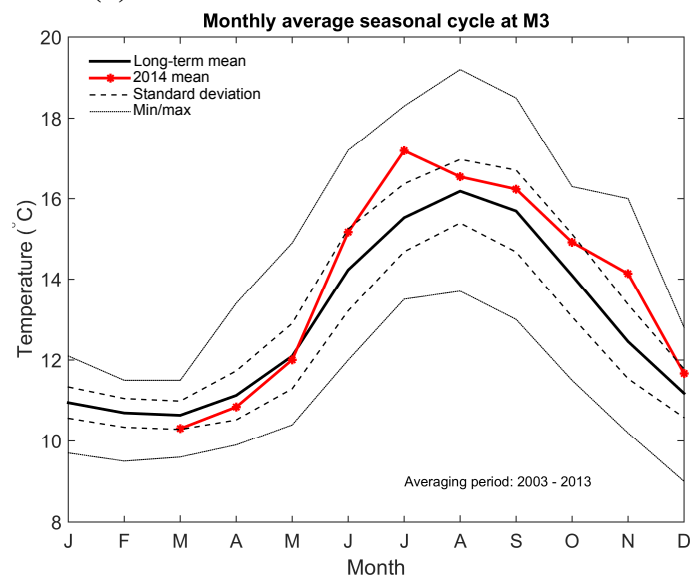

(b)

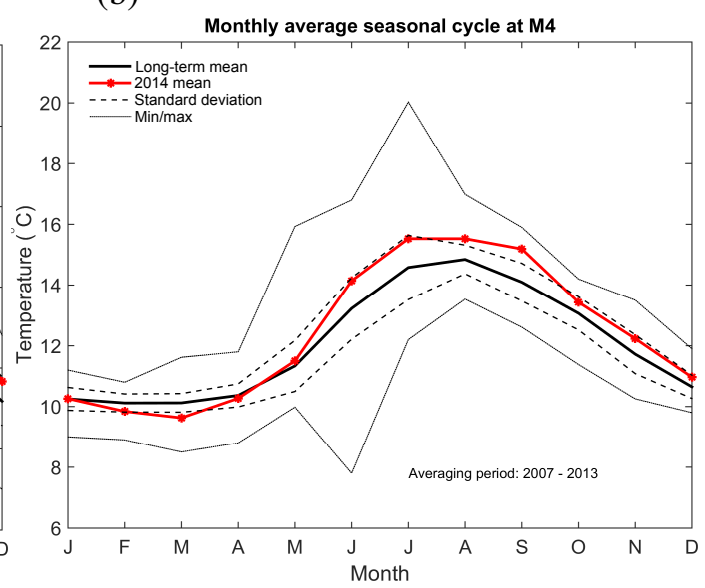

Figure 11. Monthly average seasonal cycles with 2014 monthly temperatures at the (a) $\mathrm{M} 3\left(51.2166^{\circ} \mathrm{N}, 10.55^{\circ} \mathrm{W}\right)$ and (b) $\mathrm{M} 4\left(55^{\circ} \mathrm{N}\right.$, $10^{\circ} \mathrm{W}$ ) weather buoys west of Ireland.

These developments have been driven by the end users' requirements and many are still evolving; e.g. the weekly HAB bulletin has an increasing uptake by the aquaculture farmers, whose feedback is used to reformat the presentation of data and information, including that which is model-based. The expansion of the database consisting of the observational and modelled data and products from the operational service also improves our understanding of the ecosystem functioning that in turn stimulates further development of these products and pinpoints current deficiencies that need to be addressed; e.g. there is a need for HAB monitoring on the shelf to improve the forecast skill in coastal embayments.

Presented products and services are relatively easily transferable to other geographical locations. Some will require a programming effort, e.g. coupling the shellfish ecophysiological and microbial contamination model to the ocean circulation and biogeochemical model of choice, whereas others will only need post-processing of standard ocean circulation models output and dissemination to stakeholders via user-friendly data servers, such as ERDDAP.

Acknowledgements. The authors thank their colleagues at the Marine Institute for their continued support and feedback to help shape the ocean modelling and oceanographic services. Special thanks to Damian Smyth for developing the particle tracks visualization portal. Work presented in Sect. 3.1 and 3.2 has been funded under the EU Interreg IVB EASYCO project and work presented in Sect. 3.3 has been funded under the EU FP7 ASIMUTH project, Space Theme project agreement no.: 261860.

Edited by: A. Crise

\section{References}

Ágústsson, G.: Design considerations and loads on open ocean fish cages south of Iceland, MSc Thesis, Faculty of Engineering, University of Iceland, Reykjavík, Iceland, 2004.

Beszczynska-Möller, A. and Dye, S. R.: ICES Report on Ocean Climate 2012, ICES Cooperative Research Report, No.321 Special Issue, 2013.

Booij, N., Ris, R. C., and Holthuijsen, L. H.: A third generationwave model for coastal regions, part I, model description and validation, J. Geophys. Res., 104, 7649-7666, 1999.

Bricker, S. B., Ferreira, J. G., and Simas, T.: An integrated methodology for assessment of estuarine trophic status, Ecol. Model., 169, 39-60, 2003.

Brigolin, D., Dal Maschio, G., Rampazzo, F., Giani, M., and Pastres, R.: An individual-based population dynamic model for estimating biomass yield and nutrient fluxes through an off-shore mussel (Mytilus galloprovincialis) farm, Estuar. Coast. Shelf S., 82, 365-376, 2009.

Browne, R., Deegan, B., Watson, L., MacGiolla Bhríde, D., Norman, M., Ó'Cinnéide, M., Jackson, D., and O'Carroll, T.: Status of Irish Aquaculture 2007, Report by Marine Institute, Bord Iascaigh Mhara and Údarás na Gaeltachta, 142 pp., 2008.

Cannaby, H. and Hüsrevoglu, S.: The influence of low-frequency variability and long-term trends in north Atlantic sea surface temperature on Irish waters, ICES J. Mar. Sci., 66, 1480-1489, 2009.

Canteras, J. C., Juanes, J. A., Perez, L., and Koev, K. N.: Modeling the coliforms inactivation rates in the Cantabrian Sea (Bay of Biscay) from in situ and laboratory determinations of $T_{90}$, Water Sci. Technol., 32, 37-44, 1995.

Casal, G., Furey, T., Dabrowski, T., and Nolan, G.: Generating a long-term series of SST and chlorophyll-a for the coast of Ireland. The International Archives of the Photogrammetry, Remote Sensing and Spatial Information Sciences, Volume XL-7/W3, 2015, 36th International Symposium on Remote Sensing of Environment, 11-15 May 2015, Berlin, Germany, 933-940, 2015.

Cugier, P., Struski, C., Blanchard, M., Mazurié, J., Pouvreau, S., Olivier, F., Trigui, J.R., and Thiébaut, E.: Assessing the role of 
benthic filter feeders on phytoplankton production in a shellfish farming site: Mont Saint Michel Bay, France, J. Marine Syst., 82, 21-34, 2010.

Cusack, C., Dabrowski, T., Lyons, K., Berry, A., Westbrook, G., Nolan, G., and Silke, J.: Harmful Algal Bloom forecast system for SW Ireland. Part II: Are operational oceanographic models useful in a HAB warning system?, Harmful Algae, accepted, 2016.

Dabrowski, T., Lyons, K., Curé, M., Berry, A., and Nolan, G. D.: Numerical modelling of spatio-temporal variability of growth of Mytilus edulis (L.) and influence of its cultivation on ecosystem functioning, J. Sea Res., 76, 5-21, 2013.

Dabrowski, T., Doré, W. J., Lyons, K., and Nolan, G. D.: Numerical modelling of blue mussel (Mytilus edulis) bacterial contamination, J. Sea Res., 89, 52-63, 2014a.

Dabrowski, T., Lyons, K., Berry, A., Cusack, C., and Nolan, G. D.: An operational biogeochemical model of the North-East Atlantic: model description and skill assessment, J. Marine Syst., 129, 350-367, 2014b.

Dabrowski, T., Lyons, K., Nolan, G., Berry, A., Cusack, C., and Silke, J.: Harmful Algal Bloom warning system for SW Ireland. Part I: description and validation of an operational forecasting model, Harmful Algae, accepted, 2016.

Egbert, G. D. and Erofeeva, S. Y.: Efficient inverse modeling of barotropic ocean tides, J. Atmos. Ocean. Tech., 19, 183-204, 2002.

European Commission: Directive 2006/113/EC of the European Parliament and of the Council of 12 December 2006 on the quality required of shellfish waters. Official Journal of the European Union, L 376/14, 27 December 2006.

European Commission: Blue Growth - Opportunities for marine and maritime sustainable growth - Communication from the Commission to the European Parliament, the Council, the European Economic and Social Committee and the Committee of the Regions. Luxembourg: Publications Office of the European Union, 13 pp., 2012.

FAO: The State of World Fisheries and Aquaculture 2014, Rome, 223 pp., 2014.

Fennel, K., Wilkin, J., Levin, L., Moisan, J., O’Reilly, J., and Haidvogel, D.: Nitrogen cycling in the Middle Atlantic Bight: Results from a three-dimensional model and implications for the North Atlantic nitrogen budget, Global Biogeochem. Cy., 20, GB3007, 2006.

Ferreira, J. G., Hawkins, A. J. S., and Bricker, S. B.: Management of productivity, environmental effects and profitability of shellfish aquaculture - the Farm Aquaculture Resource Management (FARM) model, Aquaculture, 264, 160-174, 2007.

Filgueira, R. and Grant, J.: A box model for ecosystem-level management of mussel culture carrying capacity in a coastal Bay, Ecosystems, 12, 1222-1233, 2009.

Grangeré, K., Ménesguen, A., Lefebvre, S., Bacher, C., Pouvreau, S.: Modelling the influence of environmental factors on the physiological status of the Pacific oyster Crassostrea gigas in an estuarine embayment; The Baie des Veys (France), J. Sea Res., 62, 147-158, 2009.

Grangeré, K., Lefebvre, S., Bacher, C., Cugier, P., and Ménesguen, A.: Modelling the spatial heterogeneity of ecological processes in an intertidal estuarine bay: dynamic interactions between bi- valves and phytoplankton, Marine Ecology Progress Series, 415 141-158, 2010.

Grant, J., Bacher, C., Cranford, P. J., Guyondet, T., and Carreau, M.: A spatially explicit ecosystem model of seston depletion in dense mussel culture, J. Marine Syst., 73, 155-168, 2008.

Guyondet, T., Roy, S., Koutitonsky, V. G., Grant, J., and Guglielmo, T.: Integrating multiple spatial scales in the carrying capacity assessment of a coastal ecosystem for bivalve aquaculture, J. Sea Res., 64, 341-359, 2010.

Holmer, M.: Environmental issues of fish farming in offshore waters: perspectives, concerns and research needs, Aquaculture Environment Interactions, 1, 57-60, 2010.

Jackson, D., O’Donohoe, P., Kane, F., Kelly, S., Mc Dermott, T., Drumm, A., Lyons, K., and Nolan, G.: Result of an epidemiological study of sea lice infestation in South Connemara, West of Ireland, Aquaculture, 364-365, 118-123, 2012.

Jauffrais, T., Marcaillou, C., Herrenknecht, C., Truquet, P., Séchet, V., Nicolau, E., Tillmann, U., and Hess, P.: Azaspiracid accumulation, detoxification and biotransformation in blue mussels (Mytilus edulis) experimentally fed Azadinium spinosum, Toxicon, 60, 582-595, 2012.

Kooijman, S. A. L. M.: Dynamic Energy Budget Theory for Metabolic Organisation, 3rd edition, Cambridge University Press, Cambridge, UK, 514 pp., 2010.

Maar, M., Bolding, K., Petersen, J. K., Hansen, J. L. S., and Timmermann, K.: Local effects of blue mussels around turbine foundations in an ecosystem model of Nysted off-shore wind farm, Denmark, J. Sea Res., 62, 159-174, 2009.

Marcaillou, C., Haure, J., Mondeguer, F., Courcoux, A., Dupuy, B., and Pénisson, C.: Effect of food supply on the detoxification in the blue mussel, Mytilus edulis, contaminated by diarrhetic shellfish toxins, Aquat. Living Resour., 23, 255-266, 2010.

Mateus, M., Pina, P., Coelho, H., Neves, R., and Leitão, P. C.: Faecal pollution modelling as a management tool in coastal areas: a case study in Estoril, Portugal, in: Ocean modelling for coastal management: Case studies with MOHID, edited by: Mateus, M. and Neves, R., IST Press, Lisbon, Portugal, 83-95, 2013.

Nolan, G., Gillooly, M., and Whelan, K.: Irish Ocean Climate and Ecosystem Status Report Summary 2009, Marine Institute, Rinville, Oranmore, Co. Galway, Ireland, 100 pp., 2010.

Novaczek, I., Madhyastha, M. S., Ablett, R. F., Johnson, G., Nijjar, M. S., and Sims, D. E.: Uptake, disposition of domoic acid by blue mussels (Mytilus edulis), Aquat. Toxicol., 21, 103-118, 1991.

Novaczek, I., Madhyastha, M. S., Ablett, R. F., Donald, A., Johnson, G., Nijjar, M. S., and Sims, D. E.: Depuration of domoic acid from live blue mussels (Mytilus edulis), Can. J. Fish. Aquat. Sci., 49, 312-318, 1992.

Nunes, J. P., Ferreira, J. G., Bricker, S. B., O'Loan, B., Dabrowski, T., Dallaghan, B., Hawkins, A., O'Connor, B., and O'Carroll, T.: Towards an ecosystem approach to aquaculture: Assessment of sustainable shellfish cultivation at different scales of space, time and complexity, Aquaculture, 315, 369-383, 2011.

Olbert, A. I., Hartnett, M., Dabrowski, T., and Mikolajewicz, U.: Long-term inter-annual variability of a cyclonic gyre in the western Irish Sea, Cont. Shelf Res., 31, 1343-1356, 2011.

Olbert, A. I., Dabrowski, T., Nash, S., and Hartnett, M.: Regional modelling of the 21 st century climate changes in the Irish Sea, Cont. Shelf Res., 41, 48-60, 2012. 
O'Sullivan, D., Lordan, C., Doyle, J., Berry, A., and Lyons, K.: Metapopulation connectivity via larval transport of the Norway lobster Nephrops norvegicus in waters around Ireland: a modelled approach, Mar. Ecol.-Prog. Ser., 534, 95-106, 2015.

Perez, O. M., Telfer, T. C., and Ross, L. G.: On the calculation of wave climate for offshore cage culture site selection: a case study in Tenerife (Canary Islands), Aquacult. Eng., 29, 1-21, 2003.

Ren, J. S., Ross, A. H., Hadfield, M. G., and Hayden, B. J.: An ecosystem model for estimating potential shellfish culture production in sheltered coastal waters, Ecol. Model., 221, 527-539, 2010.

Reynolds, R. W., Smith, T. M., Liu, C., Chelton, D. B., Casey, K. S., and Schlax, M. G.: Daily High-Resolution-Blended Analyses for Sea Surface Temperature, J. Climate, 20, 5473-5495, 2007.

Ruane, N., Geoghegan, F., Rodger, H., Murphy, K., and O'Sullivan, C.: AQUAPLAN: Health management for finfish aquaculture, Marine Research Sub-Programme (NDP 2007-2013) Series, Marine Institute, Rinville, Oranmore, Co. Galway, Ireland, ISSN 2009-3195, 34 pp., 2015.

Ryan, J.: Farming the Deep Blue Sea, Bord Iascaigh Mara - Irish Sea Fisheries Board Technical Report, available at: http://www.bim.ie/media/bim/content/downloads/ FarmingtheDeepBlue.pdf (last access: 13 January 2016), 2004.
Schlag, Z. R. and North, E. W.: Lagrangian TRANSport (LTRANS) v.2model User's Guide. Technical report of the University of Maryland Centre for Environmental Science Horn Point Laboratory, Cambridge, MD, USA, 183 pp., 2012.

Shchepetkin, A. F. and McWilliams, J. C.: The regional oceanic modeling (ROMS): a split-explicit, free-surface, topographyfollowing-coordinate oceanic model, Ocean Model., 9, 347-404, 2005.

Simons, R. A.: ERDDAP, Monterey, CA, USA, NOAA/NMFS/SWFSC/ERD, available at: http://coastwatch. pfeg.noaa.gov/erddap (last access: 13 January 2016), 2015.

Tolman, H. L.: User manual and system documentation of WAVEWATCH III version 3.14, NOAA/NWS/NCEP MMAB Technical Note 276, 194 pp., 2009.

Wohlgeschaffen, G. D., Mann, K. H., Subba Rao, D. V., and Pocklington, R.: Dynamics of the phycotoxin domoic acid: accumulation and excretion in two commercially important bivalves, J. Appl. Phycol., 4, 297-310, 1992. 